Editorial

\title{
Imagining Cities of Inclusion-Formulating Spaces of Justice
}

\author{
Anja Nygren * and Florencia Quesada \\ Development Studies, University of Helsinki, 00014 Helsinki, Finland; E-Mails: anja.nygren@helsinki.fi (A.N.), \\ florencia.quesada@helsinki.fi (F.Q.) \\ * Corresponding author
}

Submitted: 13 July 2020 | Published: 31 August 2020

\begin{abstract}
This introduction underlines some of the topics the present thematic issue focuses on, such as segregation and security, control and creativity, resistance and networking, presenting continuities and changes in urban governance and urban justice in different parts of the world. We argue that urban theory should be rethought to consider cities as fora that recentre the 'political' in relation to gentrification, rights to the city, justice, and alternative urbanisms. We highlight structural aspects of urban policy and planning, including the intersection of mega-development projects with disruptive acts of social dispossession and efforts to depoliticise institutional control. Simultaneously, we emphasise tactics that reinterpret hierarchical modes of governance and create initiatives for enhanced justice through claim-making, negotiation, improvisation, acts of everyday resistance and organised opposition.
\end{abstract}

\section{Keywords}

cities; inclusion; inequality; justice; politics; segregation; space; urban planning

Issue

This editorial is part of the issue "Cities of Inclusion-Spaces of Justice" edited by Anja Nygren (University of Helsinki, Finland) and Florencia Quesada (University of Helsinki, Finland).

(C) 2020 by the authors; licensee Cogitatio (Lisbon, Portugal). This article is licensed under a Creative Commons Attribution 4.0 International License (CC BY).

Cities around the world are developing new forms of governing risks and novel modes of urban planning, social belonging, and political decision-making. The challenges related to societal insecurity, environmental vulnerability, and political representation are enormous, especially in many parts of the global South, with two-thirds of the world's population (United Nations, 2020). This thematic issue, Cities of Inclusion-Spaces of Justice, explores new theoretical frameworks and methodological approaches to understanding the multifaceted inequalities characteristic of contemporary cities, and emergent initiatives for enhancing the rights to the city, societal security and urban justice.

We argue that urban theory should be rethought to consider cities as fora for a "re-centring of the urban political" (Dikeç \& Swyngedouw, 2017, p. 2) in order to explore past and present injustices and efforts for more just futures. Many of the articles in this issue contribute to an emerging body of scholarship that articulates politicis- ing processes with urban theory, drawing on inspirations from Michel Foucault, Nancy Fraser, David Harvey, Henri Lefebvre, Jacques Rancière, Ananya Roy, AbdouMaliq Simone, Edward Soja, Erik Swyngedouw, among others.

We aim to provide insights for researchers, planners, activists, and development practitioners in a wide range of social sciences and other fields: novel approaches that explore initiatives for alternative designs for the future. Many of these efforts operate at the crossroads of formal structures and informal networks, and at the fringes of official legitimacy and unofficial recognition, involving a diversity of actors and initiatives in the creation of more inclusive ways to engage in city life.

We focus on topics of governance and creativity, segregation and recognition, violence and security, and resistance and networking, showing continuities and changes in patterns and processes of urban governance and urban justice in a wide range of locations. Based on the authors' rich empirical knowledge, each case illus- 
trates the situated politics of these processes, demonstrating resemblances in forms of socio-spatial segregation and alternative urbanism in cities as diverse as Bogotá, Brussels, Dar es Salaam, Istanbul, Lima, Mexico City, Oslo, Santiago de Chile and Santo Domingo.

While most of the articles focus on the so-called global South, where segregation, inequality, legal pluralism and hybrid improvisation are prominent, serious problems with exclusion and hostility towards migrants in Europe are also addressed (Carlier, 2020; Tsavadaroglou, 2020). Cavicchia and Cucca (2020) identify links between urban planning and school segregation in Norway-which has been evaluated as the world's least unequal country (United Nations Development Programme, 2020)-providing important insights into how neoliberal strategies of urban planning involving spatial densification create social divisions mirrored in school segregation patterns. Urban insecurity studies involved in this issue mainly focus on Latin America, considered the most violent area in the world (Koonings \& Kruijt, 2015), with forty-two of the world's fifty most violent cities, based on homicide rates (Seguridad, Justicia y Paz, 2020).
We support a broad definition of politics that directs attention to structural aspects of urban policy and planning including the intersection of mega-development projects with disruptive acts of social dispossession, thereby destroying irregular housing, criminalising informal activities, and harming informal residents' access to collectives crucial to their urban survival and belonging (Figure 1). Relocating these residents to peripheries is not simply hazardous planning; it also supports politically motivated goals to expand state control at the 'edges,' justifying coercive policing and calculated institutional absence in the form of limited access to services and political representation (Nygren, 2018).

Socio-spatial segregation and institutional stigmatisation also link to urban violence and societal insecurity. Violent security politics, especially in the global South, rest on the intersection of authoritarian forms of governance, clientelist policies, hybridisation of responsibility, and layered modes of sovereignty (Auyero \& Berti, 2016; Coates \& Nygren, 2020). As Davis (2020) shows in this issue, in her article on Latin America, such conditions promote grey acts of policing, allowing illicit power brokers and corrupt state officials to

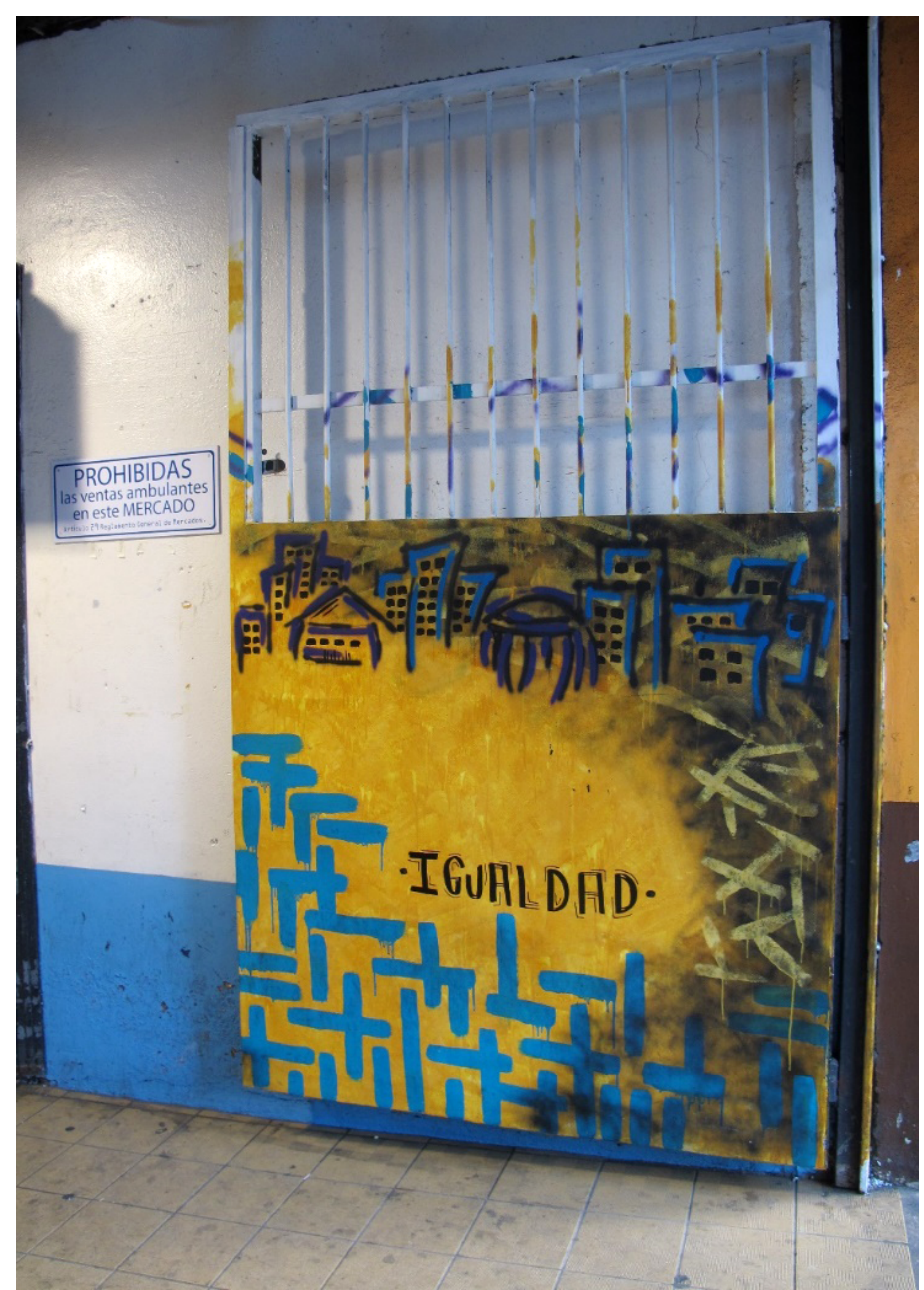

Figure 1. Popular art in the central market of San José, Costa Rica, emphasising equality, beside a sign which prohibits the access of informal traders to the market. Photo by Anja Nygren. 
institute coercion and rent-seeking as ordering principles of security politics in marginalised neighbourhoods. These extra-legal forms of control and governance by state- and non-state-armed actors in poor neighbourhoods, together with a widespread distrust in the law-enforcement capabilities of the state, further deepen the existing patterns of socio-spatial fragmentation (Koonings \& Kruijt, 2015). Davis' (2020) study shows how violent governance connects with segregation and security politics that promote authoritarian patrolling of urban zones of exception.

Critical urban theory also needs to address the depoliticising effects of neoliberal governance, in which commodification is a key principle, while neoliberal 'selfresponsibilisation' redefines political citizenship as individual responsibility for own's own well-being (Nygren, 2016). Simultaneously, participation is separated from agendas of empowerment and becomes a toolkit for transforming unruly inhabitants into responsible citizens (Vasudevan \& Sletto, 2020).

This issue also questions conventional assumptions of the omnipotence of hegemonic structures of governance, highlighting people's strategies of reinterpreting hierarchical modes of planning, and resisting uneven ways of governing through claim-making, negotiation, escaping, and situational spontaneity (Meehan, 2013; Nygren, 2016; Roy, 2011; Simone, 2020; Sletto \& Nygren, 2016). It presents attempts to (re)claim urban spaces, develop alternative forms of urbanism, and influence the urban fabric with subaltern discourses and practices, revealing the cities not only as products of formal planning and technocratic engineering, but also of resistance and improvisation (de Boeck, 2011; Simone, 2010). Vasudevan and Sletto's contribution to this issue sheds light on how residents in informal neighbourhoods of Santo Domingo engage in diverse tactics of sensemaking to process their experiences of opaque planning and threat of eviction. By deploying technocratic planning language, people negotiate with the authorities to advocate their claim, while storytelling helps build historical understanding of state interventions and speculate on the impacts of environmental ordering. People also deploy rumours, banter, and other unsanctioned speech acts to make sense of the vagaries of policies and calculate when to intervene in planning. The study provides valuable insights into how people reinterpret confusing planning procedures and reflect upon their experiences of sacrifice and their aspirations for the future.

Because informal residents rarely own the spaces they occupy, unsteadiness and precarity become a form of property, engendering violent conflicts over authority and threats of expulsion. Yet many residents are quick to capture unexpected, if restricted, opportunities provided by the frictions of urban politics (de Boeck, 2011, pp. 271-272). Exemplifying such everyday resistance is the practice of establishing 'informal' connections to formal water and electricity networks in the absence of official provision or the inability to afford consumption charges (Harris et al., 2020; Swyngedouw, 2013). The state often implicitly supports such acts as they help officials gain legitimacy and garner votes (Meehan, 2013; Nygren, 2018).

There are also initiatives that challenge the dominant power structures through more explicit refusals to work within the moral constraints of unjust policies: incipient political movements insisting on new forms of political acting (Caldeira, 2017; Dikeç \& Swyngedouw, 2017). Tsavadaroglou (2020) examines refugees' struggles in Istanbul, where authorities have transformed informal neighbourhoods into areas of high-income residence and tourism. Drawing upon the Lefebvrian concept of the right to the city and Sojan and Harveyan notions of spatial justice, Tsavadaroglou shows how gentrification subjugates refugees by physical enclosure, building demolition, and police control; by destroying refugees' social relations through dislocation; and by stigmatising their way of life. In response, refugees establish communal houses and collective kitchens to demonstrate their way of inhabiting the city through commoning practices and social togetherness. Likewise, Carlier's (2020) study on Brussels shows that the tensions between policing migration and the politicisation of new urban citizenship require the provision of 'inclusive enclaves' that allow migrants to regain the dignity necessary to get through hardships marked by hostility. Although not all such initiatives succeed in consolidating a more just order, they create new political subjectivities to challenge dominant discourses and practices.

Simultaneously, a wave of political protests is spreading across world's cities, in which those who feel subjugated are demanding new processes for constituting urban spaces politically (Dikeç \& Swyngedouw, 2017), including large-scale protests against racial bias in police work. The article by Sánchez Castañeda (2020) analyses the efforts of the Muisca Indians in Bogota to re-appropriate their sacred lands in the face of displacement and to reject hegemonic views of indigeneity through reinterpretation of their traditions as part of embodied practices of decolonisation. The study posits cities as sites for indigeneity-in-the-making, where performance of the Muisca rituals and their experiences of subjugation are part of the rebellion that displays indigenous bodies as political arenas to demand more just living conditions.

We also highlight the political character of cities through mobilisations that emerge at the crossroads of institutional marginalisation and claims for political recognition. Fuentealba and Verrest (2020) show, in their Rancièrean-inspired analysis of struggles over risk management in Santiago de Chile, how planning resilient cities has become a depoliticised governing order whereby policy-makers seek to obscure the planning's inherently political nature, while planners promote technological interventions although risk management is an issue tightly linked to politics of vulnerability. Many community initiatives disrupt such acts of de- 
politicising by breaking the silence under the prevailing order and claiming politics that challenge segregated development. Some of these efforts reject working in alignment with injustices inherent to such policies, while others develop more obvious forms of rebellion, such as civil disobedience and organised mobilisation, to engage in broad debates over equality and justice (Harris et al., 2020; McGranahan, 2016). As the contributions to this issue show, people conceptualise alternative meanings of justice through strategic alliance-buildings, quiet encroachments, everyday acts of resistance, organised mobilisations, and other forms of social contestation and symbolic disruption, often using different tactics consecutively and parallel.

The authors' detailed knowledge of the cases they discuss reveals divergent procedures of urban governance, while their empirically grounded insights into local forms of agency enhance understanding of the potential and limitations of myriad acts of resistance. Most of the studies are grounded in ethnographic analysis, semi-structured and in-depth interviews, informal conversations, oral histories, and archival and media sources. Several articles also engage in action-research and engaged ethnography. Woodcraft, Osuteye, Ndezi, and Makoba (2020) developed a novel methodology to study collective understanding of the good life in informal settlements in Dar es Salaam, showing how notions of a fulfilling life extend far beyond the macro-scale measuring of income inequality or individual life satisfaction. Their discussion demonstrates the value of epistemologies that embrace co-production of knowledge in the juxtaposition of multiple ways of living and seeing the city. Similarly, Muñoz Unceta, Hausleitner, and Dąbrowski (2020) explore the links between socio-spatial segregation, economic activities, and social interactions in Lima, revealing dynamic formal-informal intersections and how access to economic opportunities and social relations are regulated by the city's spatial structure.

Overall, we emphasise the importance of aspects of the 'political' related to gentrification, segregation, rights to the city, justice, alternative urbanisms, and practices of sense-making to urban theory. We also support approaches that recognise the difficult conditions under which many residents seek opportunities for transformation and manoeuvre. Living in a poor neighbourhood marked by punitive control and infrastructural neglect, is a painful experience that is usually constructed comparatively, with the poor acutely aware of the physical and social contrast between their surroundings (Rivke et al., 2019, p. 6), and of how gentrification and social upgrading somewhere usually coincide with marginality and downgrading elsewhere. Therefore, it is important to conceptualise procedures of (in)formalisation as relational processes (Boudreau \& Davis, 2017), in which the distribution of justice and legitimisation of authority include multifaceted debates on who is governing what, where, and why (Nygren, 2018; Zieleniec, 2018). Marginalised people's aspirations for (hyper-)modern de- velopment should also be recognised. Although many residents are aware they will never be granted access to newly designed urban spheres, the desire for more advantageous navigation through such spaces and for more inclusive belonging to the 'core' of the city is attractive compared to harsh experiences of living at the edge (de Boeck, 2011, pp. 276-278). As Tsavadaroglou (2020) points out, the right to the city includes the right to be "in the heat of the action."

Contributions to this issue call for urban redesigns that create room for mixing different types of housing and land use to break segregated spatial orders, build synergies between fragmented urban spaces and embrace cultural diversity. Several articles also emphasise strategies for empowering informal residents to gain relative autonomy from the everyday agents of violence, while others call for activities and allegiances that interlink different neighbourhoods and support the (re)invention of spaces of conviviality. Several articles also suggest methodologies of co-production that challenge institutional control and access prohibition, while envisioning transformative urbanisms.

Overall, we emphasise recognition of political initiatives and social practices that seek to transform established orders associated with exclusive governance and hierarchical decision-making. We widen urban theory to consider claims for justice that are not necessarily part of institutionalised struggles, focusing on actions rooted in people's everyday experiences (Dikeç \& Swyngedouw, 2017). As such, this issue serves as a diagnostic of the spatial politics of resistance in situations where institutional policies do not reflect citizens' sense of justice. It contributes to bringing diverse perspectives and situated geographies to urban theory, while recognising people's complex positions within the wider structures of governance and changes in urban landscapes.

\section{Acknowledgments}

This thematic issue originated from an international research seminar, "Cities of Inclusion-Spaces of Justice," which Florencia Quesada and Anja Nygren coorganized at the Helsinki Collegium for Advanced Studies, University of Helsinki, Finland, in October 2019. We are grateful to all of those who participated. The seminar and the thematic issue form part of the Fragile Cities project, funded by the Academy of Finland (grant no. 1295044).

\section{References}

Auyero, J., \& Berti, M. F. (2016). In harm's way. The dynamics of urban violence. Princeton, NJ: Princeton University Press.

Boudreau, J.-A., \& Davis, D. (2017). A processual approach to informalization: Contributions to critical studies. Current Sociology, 65(2), 151-166.

Caldeira, T. P. (2017). Peripheral urbanization: Autoconstruction, transversal logics, and politics in cities of 
the global South. Environment and Planning D, 35(1), 3-20.

Carlier, L. (2020). Experience of urban hospitality: An ecological approach to the migrants' world. Urban Planning, 5(3), 241-251.

Cavicchia, R., \& Cucca, R. (2020). Densification and school segregation: The case of Oslo. Urban Planning, 5(3), 217-229.

Coates, R., \& Nygren, A. (2020). Urban floods, clientelism, and the political ecology of the state in Latin America. Annals of the American Association of Geographers. https://doi.org/10.1080/24694452.2019.1701977

Davis, D. (2020). City, nation, network: Shifting territorialities of sovereignty and urban violence in Latin America. Urban Planning, 5(3), 206-216.

de Boeck, F. (2011). Inhabiting ocular ground: Kinshasa's future in the light of Congo's spectral urban politics. Cultural Anthropology, 26(2), 263-286.

Dikeç, M., \& Swyngedouw, E. (2017). Theorizing the politicizing city. International Journal of Urban and Regional Research, 41(1), 1-18.

Fuentealba, R., \& Verrest, H. (2020). Disrupting risk governance? A Post-disaster politics of inclusion in the urban margins. Urban Planning, 5(3), 274-287.

Harris, L. M., Wutich, A., Budds, J., Jepson, W., Pearson, A. L., \& Adams, E. A. (2020). Water sharing and the right to water: Refusal, rebellion and everyday resistance. Political Geography. https://doi.org/10.1016/ j.polgeo.2020.102245

Koonings, K., \& Kruijt, D. (2015). Urban fragility and resilience in Latin America: Conceptual approaches and contemporary patterns. In K. Koonings \& D. Krujit (Eds.), Violence and resilience in Latin American Cities (pp. 1-29). London: Zed Books.

McGranahan, C. (2016). Theorizing refusal: An introduction. Cultural Anthropology, 31(3), 319-325.

Meehan, K. (2013). Disciplining de facto development: Water theft and hydrosocial order in Tijuana. Environment and Planning $D, 31,319-336$.

Muñoz Unceta, P., Hausleitner, B., \& Dąbrowski, M. (2020). Socio-spatial segregation and the spatial structure of 'ordinary' activities in the Global South. Urban Planning, 5(3), 303-318.

Nygren, A. (2016). Socially differentiated urban flood governance in Mexico: Ambiguous negotiations and fragmented contestations. Journal of Latin American Studies, 48(2), 335-365.

Nygren, A. (2018). Inequality and interconnectivity: Urban spaces of justice in Mexico. Geoforum, 89, 145-154.

Rivke, J., Dürr, E., Jones, G. A., Angelini, A., Osbourne, A., \& Vodopivec, B. (2019). What does poverty feel like? Urban inequality and the politics of sensation. Urban Studies, 57(5), https://doi.org/10.1177\% 2F0042098018820177

Roy, A. (2011). Slumdog cities: Rethinking subaltern urbanism. International Journal of Urban and Regional Research, 35(2), 223-238.

Sánchez Castañeda, P. A. (2020). Memory in sacred places: The revitalization process of the Muisca community. Urban Planning, 5(3), 263-273.

Seguridad, Justicia y Paz. (2020). Ranking 2019 de las 50 ciudades más violentas del mundo [2019 ranking of the 50 most dangerous cities in the world]. Seguridad, Justicia y Paz. Retrieved from http://www. seguridadjusticiaypaz.org.mx/sala-de-prensa/1590boletin-ranking-2019-de-las-50-ciudades-masviolentas-del-mundo

Simone, A. (2010). Urban geography plenary lecture on intersections, anticipations, and provisional publics: Remaking district life in Jakarta. Urban Geography, 31(3), 285-308.

Simone, A. (2020). To extend: Temporariness in a world of itineraries. Urban Studies, 57(6), 1127-1142.

Sletto, B., \& Nygren, A. (2016). Unsettling neoliberal rationalities: Engaged ethnography and the meanings of responsibility in the Dominican Republic and Mexico. International Journal of Urban and Regional Research, 39(5), 965-983.

Swyngedouw, E. (2013). UN water report 2012: Depoliticizing water. Development and Change, 44(3), 823-835.

Tsavadaroglou, C. (2020). The refugees' right to the center of the city and spatial justice: Gentrification vs commoning practices in Tarlabaşı-Istanbul. Urban Planning, 5(3), 230-240.

United Nations Development Programme. (2020). United Nations development report. New York, NY: UNDP. Retrieved from http://hdr.undp.org/en/ content/2019-human-development-index-ranking

United Nations. (2020). United Nations world urbanization prospects 2018. United Nations. Retrieved from http://esa.un.org/unpd/wup

Vasudevan, R., \& Sletto, B. (2020). "They sold us illusions": Informality, redevelopment, and the politics of limpieza in the Dominican Republic. Urban Planning, 5(3), 252-262.

Woodcraft, S., Osuteye, E., Ndezi, T., \& Makoba, F. (2020). Pathways to the 'good life': Co-producing prosperity research in informal settlements in Tanzania. Urban Planning, 5(3), 288-302.

Zieleniec, A. (2018). Lefebvre's politics of space: Planning the urban as oeuvre. Urban Planning, 3(3), 5-15. 


\section{About the Authors}

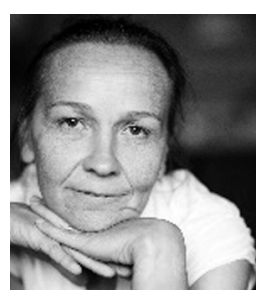

Anja Nygren is Professor of Development Studies at the University of Helsinki, Finland. She is also Affiliated Professor at Helsinki Institute of Sustainability Science (HELSUS) and at Helsinki Inequality Initiative (INEQ). Her research interests include urban governance, disasters and displacements, justice, vulnerability, urban political ecology, resource extraction, and inequality. Nygren is the leader of the research project "Fragile Cities in the Global South," which focuses on societal security, environmental safety and urban justice in Mexico, Guatemala, Colombia and India.

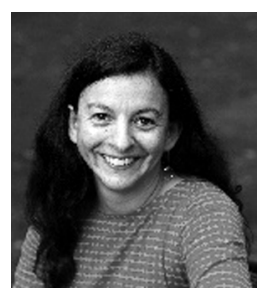

Florencia Quesada is University Researcher of Development Studies, Faculty of Social Sciences, and Adjunct Professor in Latin American Studies at the University of Helsinki. She is also affiliated at the Helsinki Institute of Sustainability Science (HELSUS). Her research interests include urban cultural history, sustainable tourism and urban planning. Quesada is part of the project "Fragile Cities in the Global South," focusing on violence and environmental risks in precarious settlements in Guatemala City. 